\title{
Impact of Use of Language on Audience's Perception: A Qualitative Analysis of Speeches by Hillary Clinton
}

\author{
Hanaa Ali Alqahtani ${ }^{1}$ \\ ${ }^{1}$ Department of Foreign Languages, Taif University, Saudi Arabia \\ Correspondence: Hanaa Ali Alqahtani, Department of Foreign Languages, Taif University, Saudi Arabia. E-mail: \\ qahtani_ha@yahoo.com
}

Received: January 25, 2019 Accepted: March 7, 2019 Online Published: May 8, 2019

doi:10.5539/ijel.v9n3p293 URL: https://doi.org/10.5539/ijel.v9n3p293

\begin{abstract}
Discourse is a fundamental factor to communicate and to identify a language or use of language. Therefore, the language used in political discourse is important for the candidates to persuade the voters. In the light of Hillary Clinton's political discourses, interviews and debates, the present study aims to identify the impact of her language on audience's perception. A total of Clinton's 29 debates and 3 interviews have been extracted from YouTube, which were transcribed in the written text. The findings of the study revealed that pronouns, metaphors, and rhetoric aspects in the speeches fulfil the strategic communicative functions. This allows the study to present a political agenda, identify the important issues, and highlight her political actions. The media portrayal of Clinton's leadership skills and language used in political speeches had a great impact on the voters. Therefore, more research should be conducted to recognize what voters want from a female candidate as a president.
\end{abstract}

Keywords: communication, political discourse, language, pronouns, Hillary Clinton, speeches

\section{Introduction}

Language serves as a tool for a person to self-identify. Through language an individual can express feelings, emotions, deliver knowledge and messages and tells stories. In other words, language allows us to understand and relate with each other (Imberti, 2007). However, language greatly influences on people by means of honesty and dishonesty and to achieve the purpose (Al-Hindawi \& Al-Aadili, 2017). Higher globalization leads to the interaction across the linguistic barriers among business managers and employees (Lauring, 2008). The language is affected by daily life aspects; therefore, there is a need to focus more on language and communication boundaries by the observers, researchers, and practitioners involved in the business management (Henderson, 2005).

Language serves as an old tool to communicate and deliver ideas to other individuals (McClay, 2017). However, language is not only a tool to communicate but serves to influence people in terms of numerous aspects (Skillicorn \& Leuprecht, 2015). For instance, speeches are a part of political campaigns just to influence the voters. Through a selective language, it offers an opportunity to both convey messages and attractive ideas, share policies, and to present a competent candidate (Kim \& Mattila, 2011). Political speech is a complete genre with its own style, organized patterns, and composite structures. All these aspects are important when assessing a presidential speech, but the core construct for these speeches is politics (McClay, 2017).

Both denotations and connotations are used by the speakers to appeal with rational and emotional perceptions to influence voters. Denotation is used to reveal the facts, policies, and conditions of the country, whereas, connotation is used to convey the messages in more convincing, appealing, and easier way so that it will be remembered by the audience (Lezana Escribano, 2017). To the political extent, it is a fruitful area where politicians work on several strategies, either honestly or dishonestly to obtain their objectives. Thus, election speeches are a powerful tool to affect the public (Al-Hindawi \& Al-Aadili, 2017). In the assessment of political discourse, linguistic and rhetoric strategies of the language are being chosen to acquire specific political effect (Lezana Escribano, 2017).

In the field of linguistics, pragmatics is the study that revolve around the meaning of aspects, not captured by the semantic theory (Jucker, 2012). Pragmatics is not only about speaking true and false, but it takes readers' attention to the facts and figures based on the truth and false statements that language often does not have in it. 
As speakers often have certain intentions and they want to accomplish all of them by using a language. Moreover, speaker wants an effect on the listeners who probably responds the speaker's intentions through their actions (Lezana Escribano, 2017).

\subsection{Objective}

The purpose of the language is significant in this study as semantic theory considers speaker's intention effective to generate audience's response. However, in political discourse; politician performs several speech acts such as: requesting, warning, informing, promising, refuting, declaring and denying, and so on. More specifically, the political communication is for the audience specially the voters to understand and believe on the candidates' words, recognize their ideology, views, opinions and whom to vote, and how to support the candidate when elections happen. Therefore, the study aims to identify the impact of the language on the audience perceptions by undertaking speeches of Hillary Clinton.

\section{Literature Review}

\subsection{Critical Discourse Analysis Using Language}

Language is not used in a vacuum, but it is used in the social, cultural, psychological, and political context. McClay (2017) revealed the powerful structure that inspires the political language. This power structure is revealed by critical discourse analysis (CDA) drawn from social theory and language. However, this critical discourse analysis has been branched into various sub-disciplines. The motivation for this study in context with (CDA) has been initiated from the popularity, unexpected appearance, and victory of Donald Trump in the presidential election of 2016. The language he used in his speech throughout the campaign has changed the acceptable standard of political discourse. Furthermore, critical discourse analysis is not a paradigm, not a homogenous model and not a school but it is the most discussed perception for doing semiotic, linguistic and discourse analysis. However, Michira (2014) covered several theories in the context of (CDA) that are mainly concerned with the use of language as a social constructive practice. Additionally, (CDA) explains the relationship between the text structure and its social operation specifically when they maintained the power relations and structures.

\subsection{Political Language}

Politicians play a smart role in increasing the empathy level of audiences as they are more aware of the policy areas as compared to others. Politicians are aware that they must take the audience to the solutions to the problems that are uncontrollable. Cichocka (2016) revealed the association between politics and language from the point of view of realistic communication and the discourse analysis. Several studies have revealed the linguistic styles used by politicians that recommend the conservative and liberal's difference in using the emotional language and multi syllabic words (Slatcher et al., 2007; Wojcik et al., 2015). Skillicorn (2015) studied the political deception done by language for the successful accomplishment in the political market. For this purpose, they must appeal to the massive audience regarding the policy issues. Deception; however, is one of the strategies as they speak and act in a different way fully accepting the facts. Speaking differently, politicians have a strong grasp on the policy area than anybody else has. They present a different image to the audience and convince them about the impact they can have on the particular area that goes beyond the candidate's official power.

\subsection{Influence of Political Debates Through Language}

Leading to these characteristics, it is revealed that the language used in the political discourse should take these features into consideration to present the right political view, to make the audience into realistic thinking, to attract and influence them and to persuade them to consider the candidate's point of views. Knight et al. (2016) studied the candidate's influence on the audience that is based on the persuasiveness of the language he uses, and the argumentation styles used in the political debates. However, the influence index has been used to evaluate the level of impact of speaker's debates on the audience. This impact is calculative by the speakers standing on the poll that is prior to the debate. Additionally, these poll scores reveal the influence political leader has on the audience and to know whether it favourably changes his electoral position in the direction to his/her campaign. Stepanyan (2015) studied some of the characteristics that are important for the political speeches regardless of language. These characteristics include aesthetics, logic, sociology, ethics, literature and linguistics. Thus, to motivate and affect the audience speakers do whatever they can do. 


\section{Methods and Materials}

\subsection{Data Collection}

During the senatorial and presidential bid between 2000 and 2008, the study consists of Hillary Clinton's discourse speeches in the three talk-shows and five debates. In terms of the longevity of Clinton's career, the main focus in this study was on her debates and speeches. The selection of this period was based on her position as the senator and a strong presidential candidate. Therefore, a rich material was presented in Clinton's discourse, which clearly explored her construction of identity.

\subsection{Debate Data}

Concerning to debates, Clinton was appeared on the 57 debates or more than that since her run for the campaign started from 2000 as a Senator till her last debate in 2016. The study focused on the time period 2000 to 2008 when Clinton participated in more than 29 debates. In which 3 debates were for the position of New York Senator and 26 debates were when running for USA president.

\subsection{Talk-Show Data}

The study focused on three of her interviews conducted during the time period 2000-2008. Two interviews were conducted by David Letterman in Letterman Late Night Show in 2000, and 2003. The other interview was with Ellen DeGeneres in Ellen Show in 2008. The first interview was conducted before the end of her tenure as the First Lady and the end of Bill's Clinton's presidency. The second interview with Letterman was conducted during her third year as a New York Senator.

\subsection{Process}

Video recordings and interviews for the study were retrieved by the links available on www.youtube.com and some other new websites. However, full recordings of the year of 2008 \& Clinton-Obama/Feb2008 were available on the news channels and were extracted from NBC News at http://www.c-span.org/. The selection of audio/visual material instead of printed text and audio recordings was deliberate.

\subsection{Transcription and Interpretation}

Four step procedures were involved in the transcription of debates and talk-shows. The videos were converted into the written texts, and all the non-linguistic features were excluded such as, hesitation markers and the paralinguistic features such as stress, intonation, kinesics and pauses.

\section{Discussion}

The findings of the study revealed the role of language used by Hillary Clinton and its impact on audience. Therefore, pronouns, metaphors, and rhetoric aspects were observed in her speeches to fulfil the strategic communicative functions of presenting political agenda, identifying the important issues and highlighting Clinton's political actions. Similarly, Spiker (2009) has enlightened Clinton's use of literal language in her different political speeches to increase the correctness, precision, and emotional vividness. Moreover, her rhetoric aspects highlighted the knowledge of complex issues, delivering a clear and consistent message i.e. ('I am a problem-solver'), competence, and use of strong language with enhanced and emotional entanglement. This reveals that Clinton just used the "rare metaphor" in her rhetoric aspects. However, this has not surprised that Clinton only uses the proverbial language in a small quantity in her speeches. The use of proverbial rhetoric has distinguished her clearly from Frederick Douglass, Abraham Lincoln, Elizabeth Cady Stanton, Susan B. Anthony, Harry S. Truman, Martin Luther King, and her friend Barack Obama (Mieder, 2014). Contrary, less use of proverbial metaphors in speeches was a deliberate choice of Hillary Clinton. As she stated, her speeches should be simple and direct, and broad and accessible to the audience. Specifically, during her role of Secretary State, it was a necessity for Hillary Clinton to be precise when communicating with foreign leaders who only understands English (Mieder, 2016).

Stewart et al. (2017) found out a significant impact of visual representation on the audience through the viewer's opinion about visual presentation. Donald Trump; through his language as well as his visual representation, revealed more sophisticated, attractive, and intelligent aspects whereas, Clinton revealed to be more competent, intelligent, and strong. This recommended that visual representation as well as language both have a significant impact on audience perception. Therefore, political ideology serves as one of the predictors and traits for candidates. However, the results of Stewart et al. (2017) are in contrast with the present study. Similar to the present study, Alayo (2016) has highlighted Clinton's speeches as an idea of America of a great nation. Through her speeches, she wanted America to be a better place by breaking the barriers and unite everybody with no exception. By doing this, Clinton gave a hope to the country through her speeches, which persuade them to believe 
in her political campaigns. However, media during the election campaign had accused Clinton for playing her gender card in her political speeches. Gilmer (2017) has analysed a period of one-week campaign during November 2007 when Hillary Clinton gave speech at Wellesley College for Presidential election. A narration related to gender i.e., "Pile On" for Clinton's team was established by media after she mentioned gender in her political discourse. Leading to this, Alayo (2016) has observed that Hillary in her political campaign mentioned her male opponents such as Bernie, Sander, Obama, and Trump. This identified that Clinton; by mentioning all these male opponents, is creating a comparison between her and them. Hence, it has established a concept of self-characterization by Clinton during her speeches. However, the present study has also revealed that Clinton in an interview with David Letterman used "I" and "You" on the same ground to show similarity between them.

\section{Finding}

Although, many literatures are present on the identity of the female politicians, the language used by them to construct their multiple identities remain inadequate by both empirical and rhetorical ways. The speeches can be classified according to the several scenarios such as the place and event on which speaker delivered that speech as the mode of transmission, the political function of the speaker, the content of the speech, and the major communicative function. The study is commenced to analyse the leadership roles that Clinton performed linguistically and the impact of language used in her political discourse on the audience.

\subsection{Reflection of National Identity}

The eight discourse speeches were chosen to conduct the study among which five were the debates and three were the interviews conducted. Even though, different political and communicative functions are to be fulfilled, all the eight speeches of Hillary Clinton were supposedly planned and constructed to be spoken to influence the audience whether the specialists or the non-specialists.

[Clinton-Obama debate, ABC News, Pennsylvania, Philadelphia, April, 2008]

\section{Clinton: well (.) we meet tonight here in Philadelphia (2) where our Founders}

2. determined that (.) the promise of America would be available (1) ah for future

3. generations if we (.) were willing and able (.) to make it happen (1) you know I am

4. here as is Senator Obama (1) neither of us were included in those (2) original

5 . documents (.) but in a very real sense we demonstrate (.) that that promise of

6. America is alive and well (2) but it is at risk (1) there is a lot of concern across

7. Pennsylvania and America (1) people do feel (.) as though their government is not (.)

8. solving problems (.) that it is not standing up for them (.) that we've got to do more

9. to (.) actually provide the good jobs that will support families (.) deal once and for all

10. with health care for every American (.) make our education system the true passport

11. to opportunity (1) restore our standing in the world (1) I am running for president (.)

12. because I know we can meet (.) the challenges of today (.) that we can continue to

13. fulfill that promise that was offered to (.) successive generations of Americans,

14. starting here so long ago (.) and I hope that, this evening (.) voters in Pennsylvania

15. and others across the country (.) will listen carefully to what we have to say (.) will

16. look at our records, will look at the plans we have (.) and I offer (.) those on my Web

17. site, hillaryclinton.com, for more detail (.) because I believe with all my heart (.) that

18. we (.) the people (.) can have the kind of future that our children and grandchildren

19. se richly deserve (.)

Figure 1. Clinton-Obama debate, April 2008

In her debate with Barack Obama, the highlighted points revealed her illustration towards the sense of national-identity and showed the unity in her discourse (Figure 1). She drew the common history related to the past events of American people referring directly to the people and audience of the country she was specifically debating about. She chose the foundation of America that referred to the people of Pennsylvania, Philadelphia as compared to other Americans. She deliberately recalled the memory in her debate to appeal them to vote for her. 
She emphasized on "we" pronoun to show her national concern.

[Clinton-Obama debate, NBC News, Cleveland, Ohio, February, 2008]

1. Interriewer: [..] a lot has been said since we last gathered in this forum, ah certainly in the

2. few days since you two last debated (1) Senator Clinton (.) in your comments especially the

3. difference has been striking (1) and let's begin by taking a look a video for CLINTON

4. attacking Obama] Senator Clinton (.) we're here in Ohio (.) Senator Obama is here (1) this

5. is the debate (1) you would agree the difference in tone over just those 48 hours was striking

6. (.)

7. Clinton: [..] you know (.) health care reform and achieving universal health care is a

8. passion of mine (.)

[Clinton Lazio debate, NBC News, 2000, New York, Decision]

1. Interviewer: [..] why did you propose (.) cutting the number of doctors by 25 percent

2. the number of specialists by 50 percent? (.)

3. Clinton: [u] (3) you know (.) in 1993 and 1994 (1) we did attempt to reform our

4. healthcare system to provide universal health care coverage [..]

Figure 2. Clinton-Obama debate, February 2008

\subsection{Reflection of Sense of Nationality}

In Clinton-Obama debate, February 2008, an opposition was accusing Clinton of being political hypocrite in terms of dealing her partisan opponent (Figure 2). Thus, instead of showing the sense of nationality, she here used the FPPP to defend herself against the accusations she got. In her second debate with Lazio, the debate was based on the ownership of healthcare system. However, in the debate of 2008, she referred the healthcare system by using FPPP "mine" and its reform as her passion. This shows that she considered herself responsible for expressing the sense of nationality rather than sharing it with the nation.

[Hillary Clinton's interview on Ellen DeGeneres, 2008]

1. Interviewer: so great to see you (.)

2. Clinton: It's great to see you (.)

3. Interviewer: you look (.) I don't know (.) how but rested and shiny and bubbly (.)

4. Clinton: here is one of the reasons (1) I have a gift for you()

5. Interviewer: really?

6. Clinton: when we were in New York together some months ago (.) we were

7. talking about (.) sometimes when you're all keyed up and you're working hard it's

8. kind of difficult to find time to sleep (.)

9. Interviewer: right (.)

Figure 3. Clinton's interview on DeGeneres

In this interview by Ellen DeGeneres in 2008, Clinton tried to establish a common ground between her and the interviewer by using FPPP "we". Clinton uses this pronoun strategically to build her positive image to achieve the set political goals (Figure 3). 


\subsection{Promotion of FPPP}

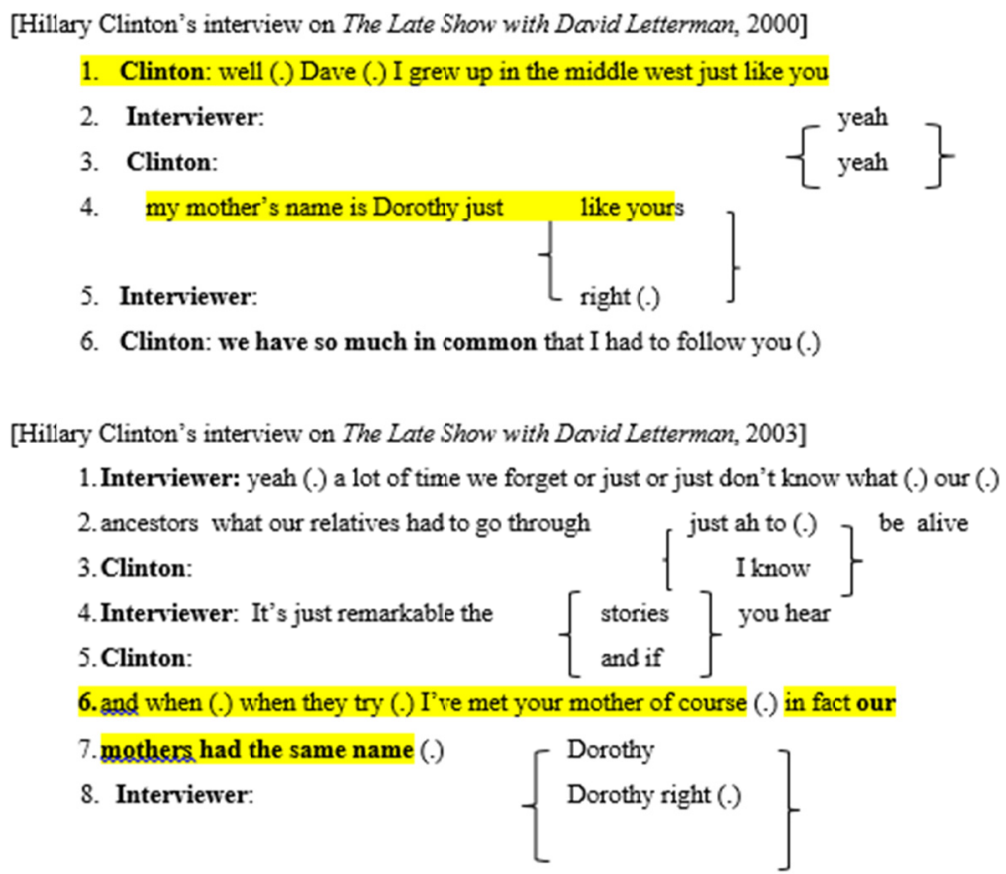

Figure 4. Clinton's interview with Letterman

In this interview by David Letterman in 2000 and 2003, she addressed similarities between her and the interviewer as she included their mother's name to create a common ground with Letterman. However, she used the second person pronoun here "I" and "you" but showed the similarity between them (Figure 4). She instead of using "my" and "yours", specifically used our FPPP which explicitly revealed her intentional use of it to build her image as a social person.

The contexts present above includes the interview with David Letterman in 2000 when she was running the campaign for the position of New York's senator. She expressed the disagreement with the interviewer by shifting the topic according to her own terms to deliver her message to the audience and the opponent. She used the in-group linguistic marker i.e., "we" to make it look better on the interviewer and the opponent. However, both contexts are completely different in genres and took place at a totally different time, but Clinton performed digressively in both contexts.

\subsection{Reflecting Expression of Fear}

[Hillary Clinton's interview on Ellen DeGeneres, 2008

1. Interviewer: alright we are going to

2. Clinton:

3. Interviewer: alright (.)

go bow1 oh my God (.)

4. Clinton: well (.) I bet there are some good bowlers in this audience (.)

5. Interviewer: I bet there are (.)

6. Clinton: oh (2) (pointing to the audience) we need some help we need

7. seme help

8. Interviewer:

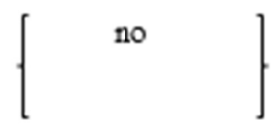

9. (2) no don't cheat (.)

Figure 5. Clinton's interview with DeGeneres (expression of fear) 
In this context, Clinton's request for help to the audience threatens the interviewer's face as well as the negative face of Clinton (Figure 5). Clinton; by interfering in the interviewer's role, she co-implicated the interviewer and her ability. Clinton's request for help was sudden that was not included in the script. Thus, her violation of rules threatens the interviewer as it could negatively express her image at stake. Moreover, Clinton's gesture to ask for help and involving the interviewer expressed her helplessness and powerless image.

The study resulted that the audience can agree or disagree with the speeches, can take participation in different way and applaud, can utter words, and speak about their sympathy. Moreover, the speeches were based on different genres because of the situations. Those eight speeches were packed with the certain linguistic forms and had certain rhetorical features. The pronouns, metaphors, and rhetoric elements were found in the speeches to fulfil the strategic communicative functions i.e., to present a political agenda, to identify the important issues, and highlight the political actions of Hillary Clinton. Her speeches consist of anaphora, metonymy, first person plural pronoun, repetition, quotations based on direct speech, and contrastive pairs. However, these features were not investigated in this study, but they were considered to be the best way of delivering the speech.

\section{Conclusion}

The use of language in Clinton's political speeches and interviews has revealed a clear impact on audience using several features such as comparison, socialization, and violation. Each pronoun and metaphor provide a new insight in her speeches, which highlights her as a country's representative. Moreover, how media portrayed her leadership abilities and language used by her in political speeches had a great impact on the voters. Therefore, future research should recognize the voter's preferences towards a female candidate as a president. The study has not compared the use of language between Clinton and Donald Trump. Thus, a study based on the recent presidential election with respect to the comparison of the two candidates' use of language should be conducted. The Clinton's visual representation style in her rhetoric elements is important for the political ideology and serves a major characteristic for each political candidate. Moreover, female representation by Clinton is also not identified in the present study; however, her political language has overshadowed the uniqueness of being the first female nominee.

\section{Acknowledgements}

The author is very thankful to all the associated personnel in any reference that contributed in/for the purpose of this research.

\section{References}

Alayo, W. R. (2016). A critical discourse analysis on the (self) representation of Hillary Clinton in public discourse. $\quad$ Retrieved from https://eprintsucmes/39008/1/Master\%27s\%20Dissertation_\%20Wendy\%20Rodriguez\%20\%28prote\%29pd $\mathrm{f}$

Al-Hindawi, F. H., \& Al-Aadili, N. M. (2017). The Pragmatics of Deception in American Presidential Electoral Speeches. International Journal of English Linguistics, 7(5), 207. https://doi.org/10.5539/ijel.v7n5p207

Cichocka, A., Bilewicz, M., Jost, J. T., Marrouch, N., \& Witkowska, M. (2016). On the grammar of politics—or why conservatives prefer nouns. Political Psychology, 37(6), 799-815. https://doi.org/10.1111/pops.12327

Gilmer, E. C. (2017). Hillary Clinton and the Media: From Expected Roles to the Critique of Feminism. The Qualitative Report, 22(10), 2533-2543.

Henderson, J. K. (2005). Language diversity in international management teams. International Studies of Management \& Organization, 35(1), 66-82. https://doi.org/10.1080/00208825.2005.11043722

Imberti, P. (2007). Who resides behind the words? Exploring and understanding the language experience of the non-English-speaking immigrant. Families in Society: The Journal of Contemporary Social Services, 88(1), 67-73. https://doi.org/10.1606/1044-3894.3593

Jucker, A. H. (2012). Pragmatics in the history of linguistic thought. The Cambridge Handbook of Pragmatics, 495-512. https://doi.org/10.1017/CBO9781139022453.027

Kim, E. E. K., \& Mattila, A. S. (2011). The Impact of language barrier \& cultural differences on restaurant experiences: A grounded theory approach.

Knight, K., Nenkova, A., \& Rambow, O. (2016). Proceedings of the 2016 Conference of the North American Chapter of the Association for Computational Linguistics: Human Language Technologies. In Proceedings 
of the 2016 Conference of the North American Chapter of the Association for Computational Linguistics: Human Language Technologies.

Lauring, J. (2008). Rethinking social identity theory in international encounters: Language use as a negotiated object for identity making. International Journal of Cross-Cultural Management, 8(3), 343-361. https://doi.org/10.1177/1470595808096673

Lezana Escribano, M. (2017). Denotation and Connotation in Hillary Clinton and Donald Trump: discourse analysis of the 2016 presidential debates.

McClay, R. (2017). A Descriptive Analysis of Donald Trump's Campaign Speeches.

Michira, J. N. (2014). The language of politics: A CDA of the 2013 Kenyan Presidential Campaign Discourse. International Journal of Education and Research, 2.

Mieder, W. (2014). All Men and Women Are Created Equal: Elizabeth Cady Stanton's and Susan B. Anthony's Proverbial Rhetoric Promoting Women's Rights. Peter Lang Publishing Incorporated. https://doi.org/10.3726/978-1-4539-1327-7

Mieder, W. (2016). "Politics is not a Spectator Sport": Proverbs in the Personal and Political Writings of Hillary Rodham Clinton. Folklore Studies/Tautosakos Darbai, 50.

Skillicorn, D., \& Christian, L. (2015). Deception in speeches of candidates for public office. Journal of Data Mining and Digital Humanities, 43. https://doi.org/10.2139/ssrn.1739282

Slatcher, R. B., Chung, C. K., Pennebaker, J. W., \& Stone, L. D. (2007). Winning words: Individual differences in linguistic style among US presidential and vice-presidential candidates. Journal of Research in Personality, 41(1), 63-75. https://doi.org/10.1016/j.jrp.2006.01.006

Spiker, J. A. (2009). It Takes a Village to Win: A Rhetorical Analysis of 'Hillary for President' Cracked but Not Shattered: Hillary Rodham Clinton's Unsuccessful Campaign for the Presidency.

Stepanyan, L. (2015). Stylistic Peculiarities of Political Speeches in English and Armenian.

Stewart, P. A., Eubanks, A. D., Dye, R. G., Eidelman, S., \& Wicks, R. H. (2017). Visual Presentation Style 2: Influences on Perceptions of Donald Trump and Hillary Clinton Based on Visual Presentation Style During the Third 2016 Presidential Debate. American Behavioral Scientist, 61(5), 545-557. https://doi.org/10.1177/0002764217707621

Wojcik, S. P., Hovasapian, A., Graham, J., Motyl, M., \& Ditto, P. H. (2015). Conservatives report, but liberals display, greater happiness. Science, 347(6227), 1243-1246.

\section{Copyrights}

Copyright for this article is retained by the author, with first publication rights granted to the journal.

This is an open-access article distributed under the terms and conditions of the Creative Commons Attribution license (http://creativecommons.org/licenses/by/4.0/). 